\title{
Guarantee of water availability and change in land use in the southern coastal area of the community of Valencia (Spain)
}

\author{
C. Juárez Sánchez R., M. Hernández Hernández \\ \& A. M. Rico Amorós \\ Institute of Geography \& Institute of Water, University of Alicante, Spain
}

\begin{abstract}
The coast and the pre-littoral zone of Bajo Segura region (Alicante) is a geographical area suffering from a natural scarcity of water resources. However, since 1960 until today, water consumption has increased due to a profound economic, demographic and landscape transformation. Statistical confirmation of this change is verified by the value reached by the use-indicators: participation in the gross domestic product, employment generated, disposable household income, population growth and concentration. The new economic trend has increased the allocation of water resources to ensure the enhancement of the territory. The water infrastructure of Tajo-Segura is that which ensures urban supply and production of the irrigated area. Overcoming water shortages involves converting the risk or bottlenecks into a great productive opportunity embodied in a growing urban/tourist impact, which reduces the irrigated area by competing for water. This dynamic urban-residential process of expansion penetrates from the coast to the inland municipalities because of the increased availability of cheap land and urban planning flexibility. As the prosperity of this area of Alicante will always be linked to solving the problem of water, water conflicts need to be resolved in order to avoid increased competition with other uses of the land. For this reason, the aim of this work is to understand and study the current status of the territorial model as well as to offer a diagnosis of the deficits, advantages and potential for better management of land and water without affecting the environment.

Keywords: tourist and residential development, water resources, comparative advantages, sustainability, water indicators, adaptive and integral management.
\end{abstract}




\section{Objective}

The aims of this work are: 1) to analyze and understand the factors that contribute most in identifying the Bajo Segura as the largest residential and tourist reception area, with a modest income and offering quality vacations to citizens of Spain and the European Union; 2) to focus on an analysis of sustainability in water resources in both quantity and quality and the pressure on natural systems and the responses made by society; 3 ) to assess the role of the investments made to find the balance between economic growth, environmental preservation and the ethics and challenges of planning and management of tourism space; and 4) due to the scarcity of renewable water resources, to achieve adaptive and integrated water management. Efforts are made to reduce pressure on demand (mass tourism) and to ensure urban supply in quantity and quality in competition with other productive uses.

\section{A geographical area with risks and opportunities for urban, tourist and residential development}

In Spain, the different regions are considered as basic units of integrated planning to reflect better geographic diversity of their productive activities and potential for change. The importance of the change is understanding that the human factor is most remarkable in shaping the new territorial model. In the case of the area under study, this process is basically the establishment and expansion of tourist-residential development and its functional relationships derived from the replacement of the traditional territorial model of agriculture, fisheries and salt by other urban services (Figure 1). The concept of a tourist-residential municipality includes both the territories bordering the sea and those favoured by the expansion of the phenomenon that radiates from the coast and penetrates towards the second line (up to 10 kilometres) looking for cheap land and flexibility in planning [1].

The tourist and residential municipalities of the coastline and its catchment area have been developed by benign natural conditions and the actions promoted by the economic policy designed by the State in the late 1960s. The comparative advantages of climate, mild temperatures throughout the year with 3000 hours of sunshine, the presence of the sea, abundance of beaches and pleasant scenery put the coastal territory in a favourable position to meet both seasonal (tourist) and permanent (residential) demands. However, these favourable natural conditions are not able by themselves to explain the expansion of the urban-tourism phenomenon. Human events such as economic policy, development of infrastructure, roads, improved accessibility and ensuring water and energy resources, are just as crucial [2].

These factors of growth in tourism have led to a profound economic, demographic, social and landscape transformation from 1960 to the present. There has been a more profitable economic and urban development confirmed statistically by the value attained by its participation in the gross domestic product, employment generated, disposable household income, dramatic increase 
in population and parallel level of concentration. The economy of the current tourist towns was linked to the management and use of natural resources of soil and water (irrigation). As the amount of water has always been scarce, wells were used to serve the developments as opposed to the irrigated area, which disappeared in some cases. Therefore in this context, the tourist process should be compared with the dynamic process resulting from socio-economic interactions which define geographical and land opportunity characteristics. That is, the economic and social growth of coastal space was a necessity required by both the local population and the development model promoted by the State.

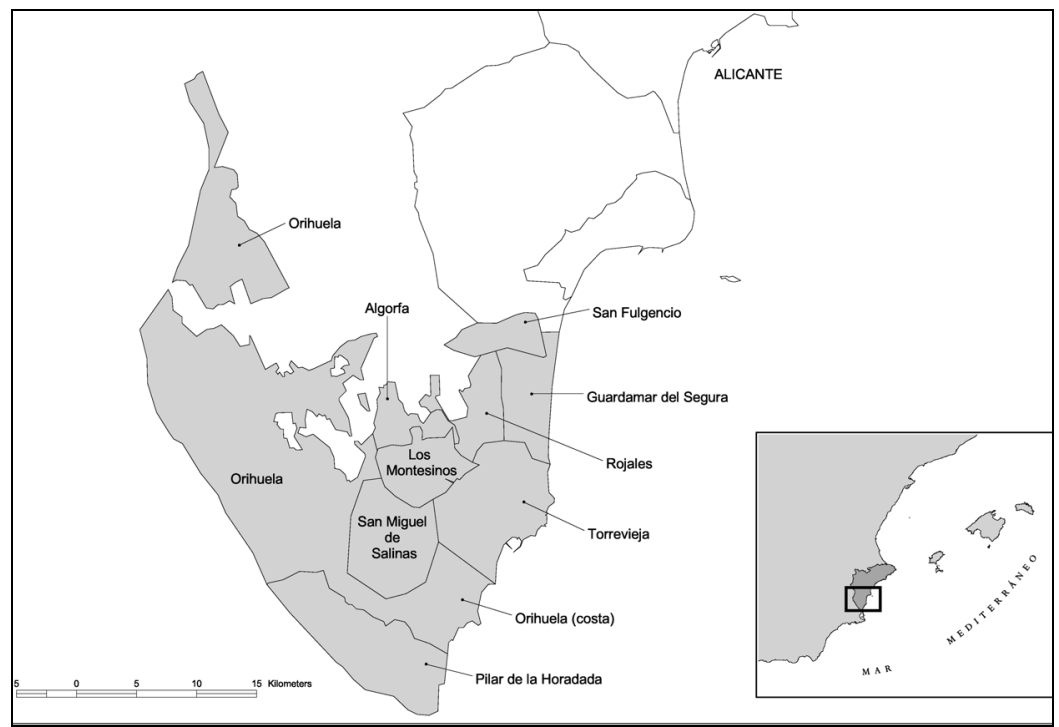

Figure 1: $\quad$ Tourist-residential towns of the Bajo Segura.

The coastal strip offers opportunities and poses problems for land use. The greater risk lies in the predominance of insufficient rainfall and high seasonal and inter-annual irregularity. The annual amount received by the coastal municipalities during the period 1950-2000, in Guardamar de Segura $287 \mathrm{~mm}$ and $255 \mathrm{~mm}$ in Torrevieja, is related to the nature of the arid climate and is insufficient in relation to the productive possibilities of agricultural development and urban expansion of tourism. The need to diversify the mainly agricultural economic production base, determines a new approach that involves a change in the system of allocating water resources to increase the exchange value of the littoral territory. This makes it necessary to consider the alternative use of water and seek solutions from the agricultural use of irrigation and tourist use, to improve economic and social viability (generation of employment). The concept of development is associated with the reduction of inequalities. Development is considered as being economical. In other words, its aim was the growth of income per capita, and then it evolved towards social and human aspects. Development should benefit all groups of people by reducing inequalities. After 
the Rio de Janeiro Summit of 1992, the concept of sustainable development was created and spread. This is also known as durable or permanent development that integrates economic growth with environmental protection and social equity (ethics). The situation of the municipalities in the coastal area was one of poverty and underdevelopment confirmed by the trend of emigration of the population to more developed urban centres. The new model of economic and social development was established in the coastal municipalities of the region and spread out to the second line (littoral), as a spread or diffuser phenomenon, creating employment and economic dependence between both territories. This process is repeated in different areas of the Costa Blanca (Marina Alta-Denia, Marina Baja-Benidorm and the Campo de Alicante-Alicante) in the province of Alicante (Figure. 1) and consists of a fast tourist and construction growth that generates a rapid increase of income capable of attracting massive immigration which means a dramatic increase in population. However, the limits imposed by water resources development are not taken into account. The demographic dynamics of the tourist towns of the southern Bajo Segura during the twentieth and twenty-first centuries is solved in two stages with different and highly contrasted characteristics. The first covers the period 1900-1950 and is characterized by a spectacular growth of vegetative positive balances that offset the negative migration. In the nineteen fifties the growth rate increased and produced high migration to other more economically dynamic areas because of inadequate agricultural profitability and the lack of industrial development and services. The second phase 1970-2005 (period of implementation and development of the tourism phenomenon under analysis) is characterized by a continuous and intense increase in immigration flows to this territory, especially from other regions of Spain, the UK, Germany and the rest of the European Union and in addition immigration from countries of Latin America and the African Continent, a population growth that continued in the period 2005-2009. This population growth is a result of the revaluation of a new territorial model of land use based on horizontal development (detached housing developments) and its penetration into the interior or the second line through the development of townhouses and residential tourist property.

\section{The role of water resources in urban-tourist developments}

This new economic orientation, especially tourism, which continued to grow, involved increasing water resource allocation to ensure the enhancement of the territory. In the Spain of the 1960s, water consumption was associated with economic development. Therefore, the increased demand generated by local authorities has been considered as an indicator of progress and quality of life for its citizens. Moving to the field of economic development, it is generally admitted that water availability determines the growth capacity of a territory. Accordingly, any action to ensure water quality and quantity in the tourist regions is justified on the basis of its positive impact on economic and social growth confirmed by raising the level of income and the generation of employment of its population. 
The water balance of the region is an indicator that reflects the reality of the unequal distribution of resources. This balance is deficient in relation to the productive possibilities of the territory of the Bajo Segura and the need for socioeconomic change. The region is characterized by the continued efforts made to increase the availability of sufficient flow in quantity and quality so as not to constrain development. This is a historical constant overtaken by successive alternatives based on the regulation of the Segura River by constructing a series of dams at the head that has allowed the management of irrigation and increase availability for urban use. This was followed by a new phase, 1960-80, characterized by basing its alternative water supply on the exploitation of groundwater and the formation of a new intensive farming that was profitable and able to export and that incorporated the new irrigation systems and practice of using greenhouses with preferential locations within the coastal strip. The increased demand and the shortage itself made it necessary for alternative uses to be considered and seek solutions from agricultural use and residential tourism of greater economic, productive and social value.

Agriculture, industry and tourism with its associated leisure time and urban consumption have increased pressure on existing water resources. In this new scenario, the aim of Spanish policy in the 1960s was to maximize gross national product growth through better utilization and conservation of water and soil resources. This economic orientation entailed a change in the system of allocating water resources to increase the exchange value of the territory. As the largest water demand increases occurred in this zone of favourable natural conditions it was decided to transfer controlled surplus water from the headwaters of the River Tajo to the territory of the provinces of Alicante and Almeria and to the region of Murcia based on criteria of final production and economic and social returns.

This particular situation of the southeast Spanish peninsular of scarce water resources in relation to the productive possibilities together with the objectives of Spanish regional policy based on the principles of efficiency (optimal allocation of resources) and equity (reducing regional disparities) prompted the creation of work on the Tajo-Segura transfer and the allocation of $110 \mathrm{hm}^{3} /$ year for urban supply [3]. However, an unexpected consequence of the introduction and expansion of tourism and residential development has been the continued increase in water needs. This has created new demands that exceed the annual amount allocated by the Law 52/1980 of 16 October. The strong increase in consumption caused by the expansion of new urban and tourist areas meant growing competition for the use of water from this transfer [4]. This high rise in consumption increases the risk of vulnerability in drought periods, alleviated by shifting flows for agricultural use to urban water supply (competitive use of water) with greater efficiency in the network and the feedback from the desalination of seawater, $42 \mathrm{hm}^{3}$ in 2005 and $76 \mathrm{hm}^{3}$ in 2008. This new alternative water supply serves to address the increasing population in the province of Alicante.

The successive alternatives of increasing water availability have led to a genuine process of land allocation for tourism and residential purposes, creating 
and fuelling new development of more productive economic return per unit of water used and of the generation of employment.

The model consisted in carrying more water resources to where there was more demand. This is what is known as management from the supply side, that is, there was no control over the usage of water in the period 1960-1995. This model has since been replaced by a more rational one based on management of the demand and driven by the enactment of the Water Framework Directive (WFD, 2000/60EC) on considering that sustainable management of water resources should be based on the principle of integrated management within water basins.

\section{Model of urban tourism development planning, population growth, types of water consumption, income level and sustainability}

The tourism model, oriented parallel to the coast line, is based on extensive occupation of coastal land favoured by the provision of road infrastructure to try to satisfy the public interest by connecting territories. This is a system of roads that contribute effectively to economic and social development by allowing transport between centres of production and consumption. However, the tourism and residential phenomenon increasingly penetrates into municipalities of the interior or second line by the increased availability of cheap land and flexibility in planning, a dynamic expansion of the tourism and residential process that has spread from the urban centres of Rojales and San Fulgencio, second line (littoral), to the towns of Algorfa and Los Montesinos [5].

In the Bajo Segura there are two growth areas: 1) the coastal area, characterized by intensive linear occupation, where housing developments have sprung up. This area includes the towns of Guardamar del Segura, Torrevieja, Orihuela - Costa, Pilar de la Horadada, and 2) the littoral area (second line) is characterized by the development of tourism-real estate with great functional dependence on the municipalities that border the sea. This progressive development of the urbanization process spreading from the coastal strip involves the need to streamline planning. A number of local entities do exist whose towns are creating economic and social links, specialization and interdependencies that go beyond the provincial border and require joint planning and coordination of specific services and works. Thus, the Generalitat Valenciana Metropolitan Areas Act promulgated by the Act of $17^{\text {th }}$ May 2001 was created which enables the management of urban growth and residential tourism, a tourism and leisure sector relying on both the new infrastructure of water availability and the likely impact of the HST (high speed train) and lowcost airlines which will encourage new expansion.

The increase in second homes has come about on the basis of the expansion of the development of townhouses as a characteristic of tourist and residential property. This singularity has identified a model characterized by few hotels and a considerable offer of secondary residences predominating. This model of tourism differs greatly from that in for example Benidorm (region of La Marina 
Baja, Alicante) both in the management of water, sanitation and waste-flows, by reducing the length of networks, and in profitability. The town of Benidorm receives 3.6 times more annual revenue from the tourism sector than Torrevieja, a model of tourist and residential development of the Lower Segura area that is more dispersed and less efficient due to the increased consumption of water/land but which is also valuable for its level of sustainability.

Statistical confirmation of the tourism and residential phenomenon in the Bajo Segura is shown by the dramatic increase in the population census in the whole county between 1960 and 2005. This went from 133,456 (100\%) inhabitants to $320,944(240 \%)$. However, this value increases significantly when the analysis is limited to new residential and tourist towns, going up from 66,759 to 242,737 inhabitants. That is, in 45 years the population has multiplied by 3.6 (Table 1). This characteristic continues when it is confirmed that in Torrevieja, the most important town, the population was in excess of 102,000 in the recount of 2009 whereas the census of 1970 only had a population of 9,700 inhabitants. The peak period of population growth was 1995-2005, when Torrevieja increased its population by just over 56,000 residents, 2,000 less than the capital of the Valencian Community (Valencia), whose average was 20 times greater.

Population growth has its corresponding impact on both the coastline and on the rest of the tourist and residential towns, a group which should include Algorfa and Los Montesinos as $20 \%$ are foreign residents (79\% and $42 \%$, respectively, from the United Kingdom). The prime consequence of the development model of sun and beach is the growth in the resident population

Table 1: Population and water consumption in $\mathrm{Hm}^{3} /$ year in the touristresidential areas of the Bajo Segura.

\begin{tabular}{|c|c|c|c|c|c|c|}
\hline Towns & $\begin{array}{c}\text { Population } \\
1981\end{array}$ & $\begin{array}{c}\text { Consumption } \\
1981\end{array}$ & $\begin{array}{c}\text { Population } \\
1991\end{array}$ & $\begin{array}{c}\text { Consumption } \\
1991\end{array}$ & $\begin{array}{c}\text { Population } \\
2005\end{array}$ & $\begin{array}{c}\text { Consumption } \\
2005\end{array}$ \\
\hline $\begin{array}{c}\text { Guardamar } \\
\text { Segura }\end{array}$ & 5,709 & 0.71 & 7,513 & 1.26 & 14,261 & 1.96 \\
\hline $\begin{array}{c}\text { Orihuela } \\
\text { town }\end{array}$ & 50,084 & 4.18 & 49,642 & 4.68 & 54,394 & 5.10 \\
\hline $\begin{array}{c}\text { Orihuela } \\
\text { cost }\end{array}$ & - & - & - & - & 23,214 & 5.51 \\
\hline $\begin{array}{c}\text { Pilar de la } \\
\text { Horadada }\end{array}$ & - & - & 7,636 & 1.28 & 19,578 & 2.75 \\
\hline Rojales & 4,136 & 0.12 & 5,227 & 0.95 & 15,987 & 2.05 \\
\hline $\begin{array}{c}\text { San } \\
\text { Fulgencio }\end{array}$ & 1,562 & 0.05 & 1,594 & 0.56 & 9,597 & 1.13 \\
\hline $\begin{array}{c}\text { San } \\
\text { Miguel de } \\
\text { Salinas }\end{array}$ & 2,317 & 0.12 & 2,867 & 0.37 & 7,104 & 0.61 \\
\hline Torrevieja & 2,321 & 2.70 & 25,891 & 5.83 & 92,034 & 9.97 \\
\hline Algorfa & - & - & 1,113 & 0.09 & 2,914 & 0.25 \\
\hline $\begin{array}{c}\text { Los } \\
\text { Montesinos }\end{array}$ & - & - & 2,267 & 0.24 & 3,654 & 0.53 \\
\hline
\end{tabular}


who are seeking to enjoy a milder climate than in their country of origin. Statistical confirmation of this process is done when it is shown that the Spanish city with the highest proportion of foreigners is San Fulgencio (Fig. 1 and Table 1) with $74 \%$ (66\% from the UK. Also, the municipality of Rojales, with more than 10,000 inhabitants where foreigners outnumber nationals by $69 \%(55 \%$ from the UK) and a percentage between 50 and $60 \%$ in the towns of Calpe, Javea and Teulada (region of La Marina, Alta-Alicante).

The allocation of water to the tourist sector (seasonal population) is not only an economic operation desirable from the standpoint of municipal and provincial requirement but of the community itself. This population has specific characteristics that differentiate it from the resident population and the factors driving the development of tourism are related to economic variables of income levels. The tourist towns account for the highest consumption of water going from $47 \%$ of the county total in 1991 to $74.5 \%$ in 2000 and $76 \%$ in 2005 , corresponding to the high concentration of resident and seasonal populations. Consequently, compared with the rest of the county, the tourism and residential areas are those with the greatest population growth, population concentration, water consumption, level of economic development (income), social (generation of employment) and environmental sustainability.

The economic viability of water used in the tourism industry improves productivity as compared with the same amount used by industrial and agricultural sectors, 18 and 35 respectively. In 1991, Guardamar del Segura had the highest level of disposable household income with 1.3 million pesetas

Table 2: Indicators of water pressure in the tourist-residential towns of the Bajo Segura.

\begin{tabular}{|c|c|c|c|c|c|c|}
\hline \multirow{3}{*}{ Towns } & \multicolumn{2}{|c|}{ Seasonal Index } & \multicolumn{4}{|c|}{$\begin{array}{c}\text { Consumption } \\
\text { (in litres/inhabitant/day } \\
(2000-2005)\end{array}$} \\
\hline & \multirow{2}{*}{2000} & \multirow{2}{*}{2005} & \multicolumn{2}{|c|}{ Pop P (2) } & \multicolumn{2}{|c|}{ Pop E (3) } \\
\hline & & & 2000 & 2005 & 2000 & 2005 \\
\hline Guardamar del Segura & 3.5 & 2.7 & 170 & 170 & 220 & 220 \\
\hline Orihuela & 2.2 & 1.3 & 250 & 225 & 250 & 230 \\
\hline Orihuela coast & 2.3 & 1.9 & 167 & 170 & 350 & 325 \\
\hline Pilar de la Horadada & 2.6 & 2.2 & 250 & 250 & 350 & 350 \\
\hline Rojales & 2.2 & 2.0 & 120 & 120 & 250 & 225 \\
\hline San Fulgencio & 2.3 & 1.9 & 175 & 175 & 220 & 220 \\
\hline San Miguel de Salinas & 1.7 & 1.6 & 150 & 150 & 220 & 220 \\
\hline Torrevieja & 3.2 & 2.4 & 140 & 126 & 200 & 180 \\
\hline
\end{tabular}


followed by Torrevieja with 1.26 million and Rojales with 1.18 million. These amounts dropped from 0.90 million in municipalities such as Algorfa and 0.84 million pesetas in Los Montesinos to a minimum of 0.52 million in interior and agricultural areas. This economic gap between the tourist and residential towns and those with an agricultural economy persisted in the period 1998 - 2003, when the largest percentage of growth in disposable income went up by $72 \%$ in Torrevieja, Rojales, San Fulgencio and Algorfa dropping to 60-72\% in Pilar de la Horadada and between $50-60 \%$ in Guardamar del Segura. In contrast, in municipalities not considered as tourist or residential, the income increase was the average for Spain, i.e. $36 \%$.

The integrated management of water resources is imperative to form both a strategy based on sustainable development by controlling the water and its use efficiently and equitably as well as the quality of reused purified water flows and their contribution to the water balance. This is a process that permits the new

Table 3: Water response indicators in the tourist-residential towns of the Bajo Segura.

\begin{tabular}{|c|c|c|c|c|c|}
\hline \multirow[t]{2}{*}{ TOWNS } & \multicolumn{2}{|c|}{$\begin{array}{l}\text { Purified flow } \\
\left(\mathrm{Hm}^{3} / \text { year }\right)\end{array}$} & \multirow[t]{2}{*}{$\begin{array}{l}\text { Usage } \\
2005\end{array}$} & \multicolumn{2}{|c|}{$\begin{array}{c}\text { Network } \\
\text { performance }\end{array}$} \\
\hline & 2000 & 2005 & & 2000 & 2005 \\
\hline $\begin{array}{l}\text { Guardamar } \\
\text { del Segura }\end{array}$ & 0.98 & 1.30 & $\begin{array}{l}\text { Agriculture: } 90 \% \\
\text { Parks-gardens:10\% }\end{array}$ & $85 \%$ & $90 \%$ \\
\hline Orihuela & 1.59 & 1.90 & $\begin{array}{l}\text { Agriculture: } 60 \% \\
\text { Ecological flow: } 40 \%\end{array}$ & $75 \%$ & $78 \%$ \\
\hline $\begin{array}{l}\text { Orihuela } \\
\text { coast }\end{array}$ & - & 2.90 & $\begin{array}{c}\text { Agriculture: } 90 \% \\
\text { Golf: } 10 \%\end{array}$ & $86 \%$ & $91 \%$ \\
\hline $\begin{array}{l}\text { Pilar de la } \\
\text { Horadada }\end{array}$ & 1.81 & 2.00 & Agriculture: $100 \%$ & $75 \%$ & $85 \%$ \\
\hline Rojales & 0.85 & 0.89 & $\begin{array}{l}\text { Agriculture: } 80 \% \\
\text { Parks-gardens:1\% } \\
\text { Golf: } 19 \%\end{array}$ & $83 \%$ & $78 \%$ \\
\hline $\begin{array}{c}\text { San } \\
\text { Fulgencio }\end{array}$ & 0.35 & 0.70 & $\begin{array}{c}\text { Agriculture: } 20 \% \\
\text { Parks-gardens: } 1 \% \\
\text { Ecological flow :79\% }\end{array}$ & $83 \%$ & $81 \%$ \\
\hline $\begin{array}{c}\text { San } \\
\text { Miguel } \\
\text { de Salinas } \\
\end{array}$ & 0.28 & 0.30 & Agriculture: $100 \%$ & $70 \%$ & $70 \%$ \\
\hline Torrevieja & 5.40 & 6.90 & $\begin{array}{l}\text { Agriculture: } 96.5 \% \\
\text { Parks-gardens: } 3.5 \%\end{array}$ & $85 \%$ & $91 \%$ \\
\hline
\end{tabular}


paradigm of sustainable development that implies economic growth and quality of life in balance with water resources. Such a process permits the implementation of successive actions of improvement through the indicators of urban sustainability of Pressure-State-Response (PSR) and the newly created analytical framework (DPSIR), corresponding to the terms of: driving forcespressure-state-impact-response (force / cause / stimulation, pressure, state, impact and response) to consider the causes and impact resulting from environmental changes in the area [6]. This is the best way of responding to the process of changes in land use in the tourist and residential area and the economic, social and environmental area (Table 3).

These actions are reflected and valued in the town of Torrevieja for both the volume of water consumed, and for the amount reclaimed and reused for agricultural use, golf courses and watering parks and gardens. A net value that varies significantly related to the equivalent number of subscribers in the period 2000 - 2005, going from a consumption of 109 litres / subscriber / day to 77 litres. This is an improved water balance because water consumption increased to $9.9 \mathrm{hm}^{3}$ (guaranteed by the provision of desalinated sea water), the amount reclaimed and reused was $6.8 \mathrm{hm}^{3}$ and the net balance was $3.1 \mathrm{hm}^{3}$ distributed among the 111,107 subscribers, up from 90,747 in 2000 , showing a consumption of 77 litres / subscriber / day. This is the model of territorial development and type of drinking water consumption in the tourist and residential area of the southern sector of the Valencian Community (Bajo Segura) that permits economic growth and environmental sustainability.

\section{Conclusions}

1) The residential and tourist municipalities of the coast of Alicante are a model of sustainability and economic, social and environmental efficiency in the Valencian Community, the Mediterranean area and the European Union. Efficient use of water allows the urban and rural development of different tourist areas, ensuring availability in quality and quantity needed for the population and preserving adequate protection of surface and ground water resources. 2) The territorial model change of the coastal and second line was produced by favourable thermal conditions, the need required by the inhabitants to overcome poverty and underdevelopment and the economic policy promoted by the State from 1960 to the present to compensate the trade balance deficit. 3) The process that is repeated in the different municipalities consists of a rapid growth in tourism and construction that generates a rapid increase of income capable of attracting massive immigration which causes a dramatic increase in the resident and seasonal population, water consumption and environmental sustainability. 4) The model of second residence tourism (Torrevieja) provides 3-6 times less annual revenue than that of the hotel industry in Benidorm (Marina Baixa). 5) the most sustainable, efficient and enduring tourist and residential model lies in integrated management of water resources as it has a more advanced and comparatively advantageous environmental infrastructure. 


\section{Acknowledgement}

This article is part of the research project "Models of land development and types of consumption of drinking water in residential tourist areas on the Alicante coastline" (CSO2009-12772-C03-03), funded by the Ministry of Science and Technology.

\section{References}

[1] Juárez Sánchez-Rubio, C., Indicadores hídricos de sostenibilidad y desarrollo turístico y residencial en la Costa Blanca (Alicante). Boletín de la Asociación de Geógrafos Españoles (47), pp. 215, 2008.

[2] Juárez Sánchez-Rubio, C., Sistemas de indicadores de sostenibilidad y desarrollo turístico. Aplicación a la comarca del Bajo Segura. Investigaciones Geográficas (33), pp.19, 2004.

[3] Juárez Sánchez-Rubio, C., Planificación hidrológica y desarrollo económico: El trasvase Tajo-Segura. Instituto de Cultura "Juan Gil-Albert": Alicante, pp.53, 1991

[4] Gil, A. \& Rico, A. M., El problema del agua en la Comunidad Valenciana. Fundación de la Comunidad Valencia Agua y Progreso: Valencisa, pp.94, 2007.

[5] Rico, A .M, Hernández, M., Ordenación del territorio, escasez de recursos hídricos, competencia de usos e intensificación de las demanda urbanoturísticas en la Comunidad Valenciana. Documents d'Anàlisi Geogràfica (51), pp.96, 2008.

[6] Vera, J. F., Ivars, J. A., Juárez, C. et al., Planificación y gestión del desarrollo turístico sostenible: propuesta para la creación de un sistema de indicadores. Documentos de Trabajo (1). Instituto Universitario de Geografía. Universidad de Alicante pp. 10, 2001. 